\title{
Design and Development of Multi Particulate System for Targeted Drug Delivery Using Natural Polymer
}

Uzma Farooq*, Rishabha Malviya and Pramod Kumar Sharma

School of Medical and Allied Sciences Galgotias University, Greater Noida, Gautam Buddha Nagar, Uttar Pradesh, India

\begin{abstract}
Okra mucilage has been used to reduce the cholesterol level since microspheres has formulated by using okra mucilage to develop a synergistic effect. Biodegradable and biocompatible okra (Abelmoschus esculentus) mucilage was extracted for the development of controlled release multi-particulate drug delivery system. Surface morphological characteristics were studied using scanning electron microscopy. Concentrated solution containing different proportion of natural materials i.e. okra mucilage and sodium alginate were used to formulate the microspheres in the calcium chloride solution. Calcium chloride act as a cross linking agent, when react with sodium alginate form a calcium alginate, since developed a gel like microspheres. The formulated microspheres were thereafter loaded with losartan potassium. These formulations were evaluated by different parameters like percentage yield, particle size, particle shape, surface morphology and in vitro release properties etc. Approximately nine formulations were studied in which F6 formulation has shown a major differentiating factor as per study. High \% yield in F7 formulation was found to be $99.01 \%$. All the formulations showed good swelling characteristics in simulated intestinal fluid (pH 7.4). During study of drug release, the rate and extent of drug release decreased significantly with increase of concentration of polymer and calcium chloride, release data shows that F6 formulation has shown a major differentiating factor given the best result of drug release which was found to be $91.50 \%$ after $6 \mathrm{hr}$ in simulated

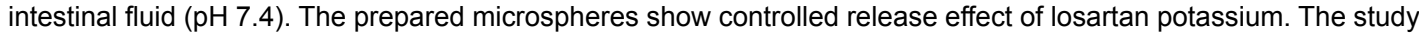
has revealed that natural materials can be used for formulation of controlled release microspheres and will provide more opportunities for further study.
\end{abstract}

Keywords: Okra; Controlled release; Natural polymer; Pharmaceutical excipient; Mucilage; Microspheres

\section{Introduction}

Natural polymers are generally obtained from plant and animal kingdom. Most of the natural polymers are high molecular weight; water soluble polymers made up of monosaccharide units and joined by glucosidic linkage [1]. Gummy exudates of natural polymers such as protein, enzyme, muscle, fibre, and polysaccharide have been used to formulate various pharmaceutical products $[1,2]$. The well-known natural polymers are gelatin, aloe mucilage, guar gum, karaya gum, bhara gum, sodium alginate, locust bean gum, okra gum and linseed mucilage. These natural polymers are applicable in different pharmaceutical dosage forms like matrix controlled systems, microspheres, nanoparticles, buccal films and viscous liquid formulations $[3,4]$. The specific application of natural polysaccharides in pharmaceutical preparation is to help in the processing of drug delivery systems during its manufacturing, protection, enhancement of stability, bioavailability and patient acceptability [5-7]. Gums have various pharmaceutical applications such as suspending agent for insoluble solid component in mixture, emulsifying agent for resin oils and adhesive in troche masses and pills [8].

Okra is an erect annual plant, botanically known as Abelmoschus esculentus (Family: Malvaceae). Polysaccharide composed of D-galactose, L-rhamnose and L-galacturonic acid. Okra is recognized for its gelatinous mucilage solution that results when it is compressed and extracted in water [9]. Okra gum has been used as a pharmaceutical excipient i.e. binder, control release, film coating, bio-adhesive and suspending agent [10]. Okra gum has been evaluated as a controlledrelease agent in customized release matrices, in contrast with sodium carboxy methyl cellulose (NaCMC) and hydroxyl-propyl-methylcellulose (HPMC), with drug [11]. Okra gum matrice provide a controlled-release of drug for more than $6 \mathrm{~h}$ and the release rate followed time-independent kinetics [12]. The result indicates that Okra gum matrices were useful in the formulation of sustained-release tablets for up to $6 \mathrm{~h}$. In addition, immature fruit have long been applied to relieve pain, moisturise skin, induce sweating, prevent scurvy and treat urinary disorders. Okra mucilage has also been used as a plasma replacement and blood volume expander. The okra mucilage is a polysaccharide composed of galacturonic acid, rhamnose and glucose since it shows hypoglycemic activities. Medicinally in treatment of several disorders, Anti-cancer, antimicrobial, anti-ulcer activity of fresh fruits is recently reported [13-15].

Natural polymers such as chitosan, gelatin, polylactic acids, okra mucilage and their derivatives have been widely studied for their ability to form microspheres $[16,17]$. These polymer-based materials are oriented to prepare microspheres and nanoparticles. So far, various studies have been reported on the development of these carriers which have been used in the preparation of microspheres. The most famous applications of microspheres are wastewater treatment, immobilization of enzymes and the preparated alginate, polystyrene, polyacrylamide, polyvinyl alcohol, nitrocellulose, etc. Recently, dosage forms that can easily and accuratly control release rate and target the drug to specific site have made great influence for the formulation and improvement of

*Corresponding author: Uzma Farooq, Research Scholar, Department of Pharmacy, School of Medical and Allied Sciences, Galgotias University, Plot No. 2, Sector 17-A, Yamuna Expressway, Greater Noida, Gautam Buddha Nagar, Uttar Pradesh, India, Tel: +919911760411; E-mail: uzma411@gmail.com

Received April 04, 2015; Accepted April 17, 2015; Published April 24, 2015

Citation: Farooq U, Malviya R, Sharma PK (2015) Design and Development of Multi Particulate System for Targeted Drug Delivery Using Natural Polymer. Pharm Anal Acta 6: 366. doi:10.4172/21532435.1000366

Copyright: ( 2015 Farooq U, et al. This is an open-access article distributed under the terms of the Creative Commons Attribution License, which permits unrestricted use, distribution, and reproduction in any medium, provided the original author and source are credited. 
novel drug delivery systems. Microspheres have given a significant role in novel drug delivery systems [18]. Multi-particulate drug delivery systems are mainly oral dosage forms which consist of multiplicity of small discrete units, each exhibit some desired characteristics. To deliver the recommended total dose, these subunits are filled in sachet, encapsulated and compressed into a tablet. For the development of multi-particulate dosage forms in preference to single unit systems because of their benefits such as increased bioavailability, reduced risk of systemic toxicity, reduced risk of local irritation and predictable gastric emptying $[19,20]$.

Losartan potassium, a non-peptide molecule, losartan is a competitive antagonist and inverse agonist of angiotensin II receptor (A-II). It is thousands times more selective for $\mathrm{AT}_{1}$ than $\mathrm{AT}_{2}$ receptor. It does not block any other receptor or ion channel, except thromboxane $\mathrm{A}_{2}$ receptor. It blocks all actions of A-II like vasoconstriction, central and peripheral sympathetic stimulation, release of aldosterone and adrenaline from adrenals, renal actions promoting salts and water reabsorption, central actions like thirst, vasopressin release and growth-promoting actions on heart and blood vessels [21].

\section{Extraction of Okra Mucilage}

Okra (Abelmoschus esculentus) was collected from local market of Greater Noida, India. Authentication of plant material has done by Dr. Vikrant Jain, PhD (Botany), Department of Biotechnology, Gautam Buddh University, Greater Noida, certificate as shown in Figure 1. As author previously described, collected okra (Abelmoschus esculentus) was carefully washed and dried under shade for $24 \mathrm{~h}$, further dried in the oven at $30-40^{\circ} \mathrm{C}$ for $5-6 \mathrm{~h}$ to obtain the constant weight. Size was reduced through grinder. Powdered fruit passed through sieve no. \#22 and was stored in air tight container for further used. Extraction of mucilage includes two steps.

\section{Extraction of mucilage}

As described elsewhere, powdered fruit was put in $1000 \mathrm{ml}$ beaker containing $500 \mathrm{ml}$ of distilled water, then heated and stirred continuously at $60^{\circ} \mathrm{C}$ for approximately $4 \mathrm{~h}$. Concentrated solution was filtered through muslin cloth and cooled at $4^{\circ} \mathrm{C}-6^{\circ} \mathrm{C}$ [22].

\section{Isolation of Mucilage}

As described previously [22], extracted gum has isolated in ethyl

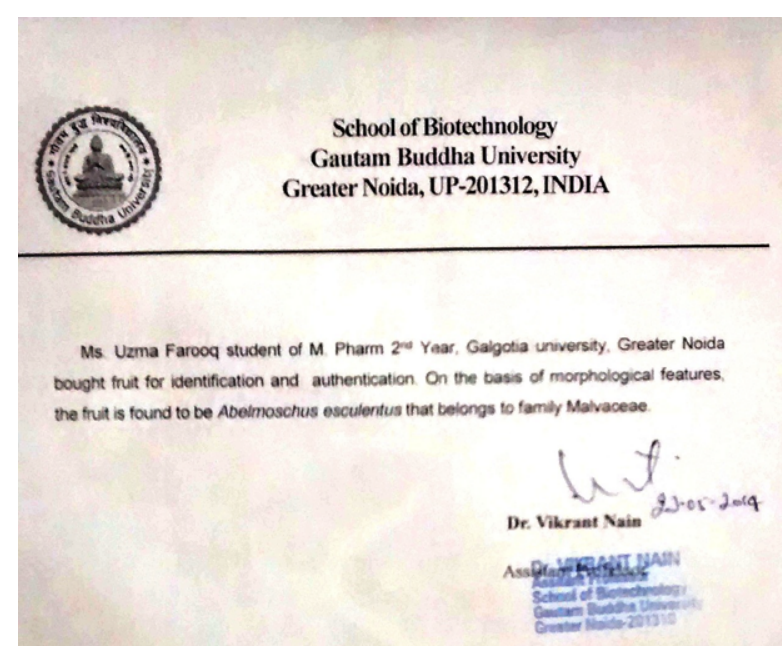

Figure 1: Authentication certificate plant material. alcohol. This allows filtration through muslin cloth. Washed with ethyl alcohol and the mucilage filtrated through muslin cloth. Pressed mucilage was further dried to constant weight at $35-45^{\circ} \mathrm{C}$ in hot air oven. Hard mucilage cake was grinded and sieved through sieve \# 22, stored in dessicator for further used [23].

\section{Determination of carbohydrates presence in okra mucilage}

Aqueous extract was mixed with Molish's reagent followed by addition of sulphuric acid. The violet colour ring appeared at junction, showing presence of carbohydrates [24].

\section{Determination of purity of okra mucilage}

To measure the purity of extracted mucilage, tests for alkaloids, proteins, gum, fats, tannins and amino acids were performed [25].

\section{Organoleptic evaluation of isolated mucilage}

Isolated mucilage was characterized for organoleptic properties such as colour, odour, taste, fracture and texture [26].

Ash values: Ash values such as total ash, acid insoluble ash and water- soluble ash were determined using equation 1, 2, 3 respectively [27].

Total Ash Value=weight of ash

$$
\begin{aligned}
& \text { Total ash value } \frac{\text { weight of ash }}{\text { weight of polymer }} \times 100 \\
& \text { Acid insoluble ash } \frac{\text { weight of acid inso luble ash }}{\text { weight ofdried powder }} \times 100 \\
& \text { Water soluble ash } \frac{\text { weight of Water soluble ash }}{\text { weight of dried powder }} \times 100
\end{aligned}
$$

Solubility behaviour: Dry polymer powder was shaken with different solvents and further solubility was determined [27].

pH of mucilage: The mucilage was weighed and dissolved in water separately to get a $1 \% \mathrm{w} / \mathrm{v}$ solution. The $\mathrm{pH}$ of solution was determined using digital $\mathrm{pH}$ meter [28].

\section{Swelling index}

Swelling index was calculated as per equation 4 [28].

$$
\text { Swelling index }=\frac{\text { final volume }- \text { initial volume }}{\text { final volume }} \times 100
$$

Surface tension: The surface tension of the selected mucilage was determined by drop weight method, using a stalagmometer. The surface tension of the polymer has been reported to influence the binding quality of the polymer. Surface tension was calculated as per equation $5[28,29]$.

$\sigma_{\text {solution }}=\sigma_{\text {water }} \frac{m(\text { solution })}{m(\text { water })}$

Where, $\sigma_{\text {solution }}=$ surface tension of solution

$\Sigma_{\text {Water }}=$ Surface tension of water

$\mathrm{m}$ (solution) $=$ Weight of solution

$\mathrm{m}$ (water)=weight of water

Viscosity: The viscosity of $0.25 \%$ solution of polymer was 
determined using Oswald viscometer, calculation were done using equation $6[29]$.

$$
\eta_{s}=\eta_{w} \times \frac{t_{s} \rho_{s}}{t_{w} \rho_{s}}
$$

Where

$\eta_{s}=$ Viscosity of solution

$\eta_{w}=$ Viscosity of water

$\mathrm{t}_{\mathrm{s}}$ and $\mathrm{t}_{\mathrm{w}}=$ Time of solution and water respectively

$\rho_{\mathrm{s}}$ and $\rho_{\mathrm{w}}=$ Density of solution and water

Loss on drying: One gram of powder was weighed accurately in a weighing bottle and was dried in a hot air oven at $105^{\circ} \mathrm{C}$ and the weight was checked at intervals of $10 \mathrm{~min}$, until a constant weight was obtained. The percentage of weight lost by the powder was calculated using equation 7 [30].

$$
\text { Loss on drying }=\frac{\text { initial weight }- \text { final weight }}{\text { initial weight }} \times 100
$$

Bulk density and bulkiness: Inverse of bulk density is called bulkiness. Accurately weighed quantity of $(50 \mathrm{~g})$ was introduced into a graduated measuring cylinder. The cylinder was fixed on the bulk density apparatus and the volume occupied by the powder was noted. Then, the powder was subjected to tapping in a bulk density apparatus until constant volume was obtained. The final volume (bulk volume) was noted. Bulk density, tapped density and bulkiness were calculated using equation 8-10 respectively $[28,29]$.

$$
\begin{aligned}
& \text { Bulk density }=\frac{\text { Weight of Powder blend }}{\text { weight of apparent volume }} \\
& \text { Tapped density }=\frac{\text { weight of powder blend }}{\text { tapped volume }} \\
& \text { Bulkiness }=\frac{1}{\text { bulk density }}
\end{aligned}
$$

Powder flow property: This property is also known as compressibility. Finely powdered polymer $(5 \mathrm{~g})$ was passed through a funnel fixed on a stand at a specific height upon graph paper and calculations were done as per equation 11,12 [21].

$$
\begin{aligned}
& \operatorname{Tan} \theta=\frac{\text { Height }}{\text { radius }} \\
& \theta=\tan ^{-1} \frac{h}{r}
\end{aligned}
$$

Where

$$
\begin{aligned}
& \theta=\text { angle of repose } \\
& \mathrm{h}=\text { height of pile } \\
& \mathrm{r}=\text { radius of pile }
\end{aligned}
$$

Powder Compressibility (Carr's Consolidation Index): This property is also known as compressibility. Carr's consolidation index was calculated using equation 13 and 14 [21].

$$
\begin{aligned}
& \text { Carr's index }=\frac{\text { tapped density }- \text { bulk density }}{\text { tapped density }} \times 100 \\
& \text { Hausner's ratio }=\frac{\text { tapped density }}{\text { bulk density }}
\end{aligned}
$$

Particle size analysis: Particle size distribution of the polymer was determined by optical microscopy method. The diameters of at least 50 particles of each slide were measured using a calibrated eye piece micrometer (thrice), which was calculated as per equation 15 and 16 [21].

Size of individual particle $=$ No.of individual in eye piece $\times$ Calibration factor

$$
\text { Calibration factor }=\frac{\text { stage reading } \times 0.01}{\text { ocular reading }}
$$

Preparation of microspheres: Aqueous phase was formed by slowly adding $3 \%$ sodium alginate in $20 \mathrm{ml}$ of distilled water and stirred with magnetic bead at constant temperature of $50-60^{\circ} \mathrm{C}$. And followed by mixing of okra mucilage powder at different concentration as per formulation given in the Table 1 with continuous stirring and then $200 \mathrm{mg}$ losartan potassium (drug) was added in each formulation with continuous stirring at $35-40^{\circ} \mathrm{C}$ till completely dissolve to make a viscous solution.

Different concentration of calcium chloride as per formulation given in the Table 1 had dissolved in $50 \mathrm{ml}$ of distilled water. Aqueous phase was slowly added through $22 \#$ needle in the calcium chloride solution within $15 \mathrm{~min}$ with continuous stirring through magnetic bead at room temperature, curing time $30 \mathrm{~min}$ should be taken in all the formulations. Microspheres filter and two times washed with $50 \mathrm{ml}$ distilled water. Collected microspheres had dried in oven at $37-40^{\circ} \mathrm{C}$ till completely dried.

\section{Evaluation of Microspheres}

\section{Percentage yield $(w / w)$}

The dried microspheres were weighed and their percentage yield (w/w) was measured by using following formula [25].

$$
\% \text { yield }=\frac{\text { Amount dried microbead recovered }}{\text { Amount of drug }+ \text { Amount of polymer }}
$$

\section{Shape and surface morphology}

The external morphology of microspheres was analyzed by scanning electron microscope (SEM). For scanning electron microscopy samples was equipped by lightly sprinkling microspheres powder on a double adhesive tape, which fixed to an aluminium stub. The stubs was then inserted into the apparatus EMITECH (K550X) SPUTTER for gold coating to a thickness of $150-200 \mathrm{~A}^{\circ}$, gold coating has conducted for conductivity to neutralize the charge of the given sample. Coated microspheres were examined under scanning electron microscope using apparatus ZEISS [30,31].

\begin{tabular}{|c|c|c|}
\hline Formulation & $\begin{array}{c}\text { Concentration of okra } \\
\text { polymer (\%) }\end{array}$ & $\begin{array}{c}\text { Concentration of } \\
\text { calcium chloride (\%) }\end{array}$ \\
\hline F1 & 2 & 7 \\
\hline F2 & 2 & 3 \\
\hline F3 & 2 & 5 \\
\hline F4 & 1 & 7 \\
\hline F5 & 1 & 3 \\
\hline F6 & 1 & 5 \\
\hline F8 & 1.5 & 7 \\
\hline F9 & 1.5 & 3 \\
\hline
\end{tabular}

Table 1: Concentration data of okra polymer and calcium chloride in different formulation. 


\section{Angle of repose}

Weighed quantity of microspheres was passed through a funnel fixed on a stand at a specific height upon graph paper. A static heap of microspheres with gravity acting upon it was tending to appear a conical mound. The height of the heap $(\mathrm{h})$ and radius $(\mathrm{r})$ of lower part of cone was calculated. The angle of repose was calculated using above equations 11 and 12 [32,33].

\section{Carr's index}

The simple tests evaluate the flow ability of powder by compare the poured density and tapped density of a powder. It was resolute by taking small amount of microspheres samples in $10 \mathrm{ml}$ measuring cylinder [34]. The height of the sample was calculated before and after tapping indicates the poured and tapped density. Carr's index was calculated as:

$$
I=\frac{V_{b}-V_{t}}{V_{b}} \times 100
$$

Where $\mathrm{V}_{\mathrm{b}}$ is bulk volume and $\mathrm{V}_{\mathrm{t}}$ is tapped volume.

\section{Hausner's ratio}

Hausner's ratio was calculated using formula:

$$
\text { Hausner's ratio }=\frac{\rho_{t}}{\rho_{d}}
$$

\section{Equilibrium swelling studies of microspheres}

Swelling index was analysed by measuring the degree of swelling of microspheres. To certify complete equilibrium, accurately weighed 100 $\mathrm{mg}$ of microspheres was allowed to swell in imitation stomach $\mathrm{pH} 1.2$ for $2 \mathrm{~h}$ and then simulated intestinal fluid $\mathrm{pH} 7.4$ for $10 \mathrm{~h}$. The excess surface adhered liquid drops were removed by blotting and swollen microspheres were weighed by using microbalance. The degree of swelling was then calculated by the following formula $[35,36]$.

$$
\text { Degree of Swelling }=\frac{M_{0}-M_{t}}{M_{t}} \times 100
$$

Where $M_{t}=$ initial weight of microspheres and $M_{0}=$ weight of microspheres at equilibrium swelling in the media.

\section{In vitro drug release}

The in vitro dissolution studies were performed at two different $\mathrm{pH}$ values: (i) $1.2 \mathrm{pH}$ (simulated gastric fluid) and (ii) $7.4 \mathrm{pH}$ (simulated intestinal fluid). In vitro drug release studies were carried out using US Pharmacopoeia basket type dissolution apparatus at $37 \pm 0.5^{\circ} \mathrm{C}$ with constant stirring rate of $50 \mathrm{rpm}$. Microspheres equivalent to $10 \mathrm{mg}$ of losartan potassium were used for the test. An accurately weighed sample was responded in dissolution media consisting $500 \mathrm{ml}$ of 0.1 $\mathrm{N}(\mathrm{pH}$ 1.2) $\mathrm{HCl}$ and dissolution was done for $2 \mathrm{~h}$. The dissolution medium was then replaced with $\mathrm{pH} 7.4$ phosphate buffer $(900 \mathrm{ml})$ and drug release study was carried out for further $6 \mathrm{~h}$. A sample volume of 5 $\mathrm{ml}$ was withdrawn from each dissolution vessel at regular intervals and replaced with equal volume of fresh dissolution medium. The sample was filtered and analyzed spectrophotometrically at $206 \mathrm{~nm}$ using a UV-Visible spectrophotometer (UV-1800, Shimadzu) [37-39].

\section{Stability study}

Optimized formulation was subjected for stability studies, which were stored in glass bottles at $25^{\circ} \mathrm{C} / 60 \% \mathrm{RH}$ (Relative humidity), $30^{\circ} \mathrm{C} / 65 \% \mathrm{RH}$ and $40^{\circ} \mathrm{C} / 75 \% \mathrm{RH}$ for a period of 45 days. Microspheres

\begin{tabular}{|c|c|c|}
\hline S. No & Test & Present/absent \\
\hline 1. & Carbohydrates & + \\
\hline 2. & Hexose Sugar & + \\
\hline 3. & Monosaccharides & - \\
\hline 4. & Proteins & - \\
\hline 5. & Fats and oils & - \\
\hline 6. & Tannins and Phenolic Compounds & - \\
\hline 7. & Alkaloides & - \\
\hline 8. & Amino acids & + \\
\hline 9. & Mucilage & - \\
\hline 10. & Gums & - \\
\hline
\end{tabular}

Table 2: Determination of purity of isolated mucilage.

\begin{tabular}{|c|c|c|}
\hline S No & Parameters & Values \\
\hline 1. & Angle of repose $\left({ }^{\circ}\right)$ & $27.29 \pm 0.050$ \\
\hline 2. & Carr's index $(\%)$ & $76.42 \pm 0.249$ \\
\hline 3. & True density $(\mathrm{gm} / \mathrm{ml})$ & $3.05 \pm 0.060$ \\
\hline 4. & Bulk density $(\mathrm{gm} / \mathrm{ml})$ & $0.690 \pm 0.004$ \\
\hline 5. & Bulkiness $(\mathrm{ml} / \mathrm{g})$ & $1.46 \pm 0.015$ \\
\hline 6. & Mean particle size $(\mu \mathrm{m})$ & $52.50 \pm 0.050$ \\
\hline
\end{tabular}

Table 3: Micromeritic study data of mucilage.

from each batch of formulation was taken at the end of 15,30 and $45^{\text {th }}$ day which were subjected for drug content and $\%$ drug release studies $[40,41]$.

\section{Result and Discussion}

As author previously described, after extraction and further precipitation by ethyl alcohol the yield of mucilage was $11.44 \% \mathrm{w} / \mathrm{w}$ obtained. The isolated sample was subjected to identification; this showed presence of carbohydrates in sample powder. Confirmation of mucilage was done when it gave negative test for tannins, alkaloids and proteins. This can be considered as proof for purity of the isolated mucilage as depicted in Table 2.

The results for loss of drying showed value of $9.917 \%$. This indicated that mucilage is hygroscopic in nature and need to be stored in air-tight containers. Okra mucilage was found to be soluble in warm water, slightly soluble in cold water and insoluble in benzene, ether, chloroform, n-butanol, ethanol, acetone, glycerine, paraffin. $\mathrm{pH}$ of $1 \%$ solution was found to be $7.5 \pm 0.5$ and its surface tension of $0.25 \%$ $\mathrm{w} / \mathrm{v}$ solutions of mucilage was found to be $0.0405 \mathrm{~J} / \mathrm{m}^{2}$. Other phytoconstituents were absent in the isolated powder. Irregular particles size was found to be $52.50 \mu \mathrm{m}$. Result obtained of okra mucilage and observed that mucilage is brownish colour, odourless, tasteless, rough and irregular in shape. Ash values were calculated to characterize mucilage; total ash, acid insoluble ash and water soluble ash were found $7.53 \%, 0.93 \%$ and $4 \%$ respectively. Physical characterization of mucilage was carried out for bulk density and bulkiness, true density, total porosity, powder flow behaviour. The bulkiness value indicated that powder is 'heavy' in nature. Result obtained in micromeritic characterization of mucilage was shown in Table 3.

The SEM photograph as shown in Figure 2 of the Abelmoschus esculentus mucilage revealed that the surface of the particles was found to be rough and irregular. Earlier, it has been reported that rough surface of polymer can retard the drug release from the dosage form due to the entrapment of drug in the pores. The used polysaccharides (polymers) were found to be insoluble in organic solvents such as ethyl alcohol, benzene, chloroform etc, which leads to insoluble precipitate. 


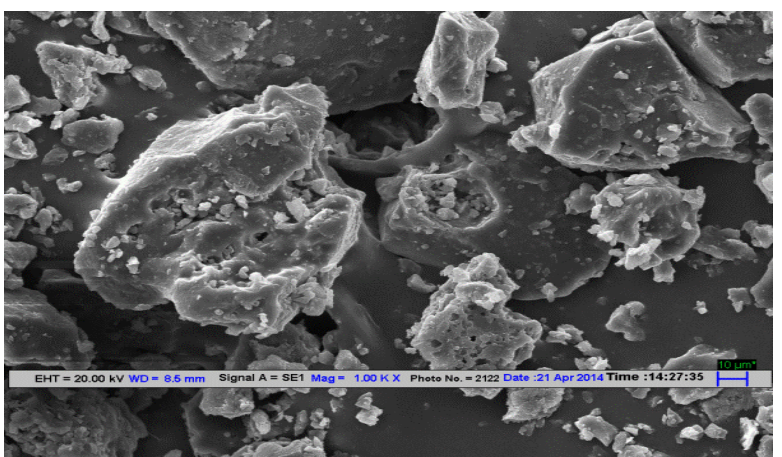

Figure 2: Scanning electron micrograph of Abelmoschus esculentus mucilage.

\begin{tabular}{|c|c|}
\hline Formulation & \% yield \\
\hline F1 & $98.06 \pm 0.056$ \\
\hline F2 & $93.03 \pm 0.030$ \\
\hline F3 & $90.09 \pm 0.036$ \\
\hline F4 & $98.04 \pm 0.036$ \\
\hline F5 & $91.02 \pm 0.032$ \\
\hline F6 & $92.05 \pm 0.033$ \\
\hline F7 & $99.01 \pm 0.034$ \\
\hline F8 & $97.06 \pm 0.037$ \\
\hline F9 & $93.04 \pm 0.035$ \\
\hline
\end{tabular}

Table 4: Comparative studies on the bases of \% yield.

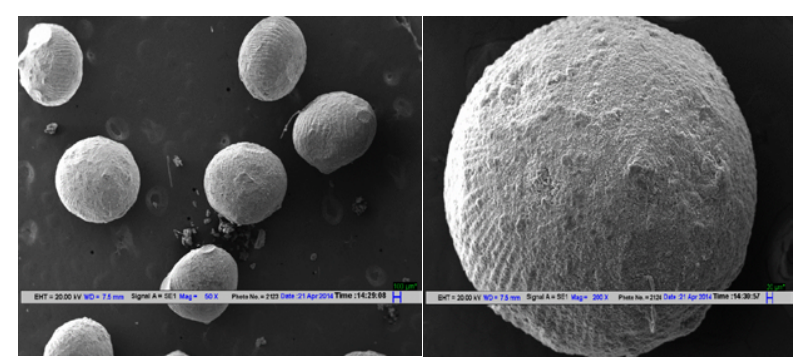

Figure 3: Scanning electron micrograph (SEM) of formulations (F4 and F6).

They developed the colloidal mucilaginous dispersion in water, saturated saline and showed a good swelling property in phosphate buffer of $\mathrm{pH}$ 7.4. The $\mathrm{pH}$ of $1 \%$ aqueous dispersion of sodium alginate and Abelmoschus esculentus (okra mucilage) was found to be 7.2 and 7.5 , respectively, which indicate the compatibility to the alkaline $\mathrm{pH}$ of the intestine. These properties were significantly used in controlled drug delivery.

The prepared multi-particulate formulations are of brownish colour, spherical in shape, and have a rough surface. In case of percentage yield of microspheres all the formulation has given the fluctuated yield due variation in concentration of polymer and calcium chloride, as per study F7 formulation has given a maximum yield as shown in Table 4.

The SEM of the drug loaded microspheres shows spherical and rough surface of all the formulations. However, deepening was found due to loss of solvent during drying. It was found that polymer concentration, rpm of the mechanical stirrer, temperature and curing time affected the shape and size of microspheres. The SEM photomicrographs are shown in Figure 3; concentration of sodium alginate influences the surface morphology of beads at higher concentration sodium alginate formed discrete and spherical shape with a rough outer surface and visible large wrinkles have a sandy appearance might be due to surface-associated crystals of drug.

Mean particle size of different formulations loaded with $200 \mathrm{mg}$ of the drug was given in Table 5, in which F5 formulation has shown the minimum particle size $(240.72 \mu \mathrm{m})$. It was found that the particle size distribution was within a narrow size but the mean particle size was different among the formulations. The results indicated that the proportional increase in the mean particle size of microspheres increased due to the variability of okra polymer and calcium chloride in the formulations.

The rheological parameters like angle of repose, bulk density and tapped density of microspheres confirms better flow and packaging properties. All the formulations showed excellent flow ability represent in terms of angle of repose $\left(<40^{\circ}\right)$. Micromeritic studies were conducted of all the formulations in which F6 formulation has given a maximum bulk density.

As compared to all the formulations of $\mathrm{F} 6$ formulation has shown the maximum bulk density and tapped density i.e. $1.06 \pm 0.0866$ and $1.29 \pm 0.11 \mathrm{gm} / \mathrm{ml}$ respectively, while $\mathrm{F} 3$ formulation has shown a least bulk density which was found to be $0.87 \pm 0.02$ respectively. All the formulations have excellent flow property but F6 has given the better flow property as compared to other formulations.

The swelling ratio of the formulation (F1-F9) vary by increasing in the concentration of sodium alginate was observed under $\mathrm{pH}$ 1.2 acidic buffer, $\mathrm{pH} 7.4$ phosphate buffers up to $4 \mathrm{~h}$. Under acidic conditions swelling of calcium alginate beads occurs scarcely. The low swelling in acidic media $\mathrm{pH} 1.2$ was probably due to proton-calcium ion exchange forming insoluble alginic acid regions and followed by solvent penetration into the gel network. Under neutral conditions the beads will swell and the drug release depends on the swelling and erosion process (Table 6).

Stability studies were performed on F1, F3, F5, F7 and F9 formulations at $45^{\circ} \mathrm{C}$ and $75 \% \mathrm{RH}$ for 45 days. On the basis of stability studies data all formulations were found to be stable which were checked by the evaluation two parameters, such as \% drug content and \% drug release. These studies revealed that F1, F3, F5, F7 and F9 formulations showed slight decrease in drug content as well as \% drug release at interval of $0,13,30,45^{\text {th }}$ day, maximum stability were observed in F9 formulation due to maximum \% of drug content and drug release (Tables 7 and 8).

Losartan potassium release from formulated microspheres have been performed in different media, initially in simulated gastric fluid (SGF) $\mathrm{pH} 1.2$ ( $\mathrm{HCl}$ buffer solution) for $2 \mathrm{~h}$, then continue in phosphate buffer $\mathrm{pH} 7.4$ for the period up to $6 \mathrm{~h}$. The drug release from microspheres was $\mathrm{pH}$ dependent, all the formulations showed negligible drug release in acidic $\mathrm{pH} 1.2(<15 \% \mathrm{w} / \mathrm{w})$ may be due to the stability of polymers at lower $\mathrm{pHs}$ and conversion of $\mathrm{Ca}$-alginate to the insoluble alginic acid to formed tightening of the gel mesh work. On the other hand, the polymer is eroded at alkaline $\mathrm{pH}$ and the contents are released in a sustained manner by both diffusion and slow erosion of polymer matrix. Since polymers are soluble in high $\mathrm{pH}$ and not soluble in acidic environment, it means drug has easily penetrated through the tissue by micro-particulate drug delivery system.

As the drug-polymer ratio increased, the release rate of losartan potassium from the microspheres decreased as evident from Table 8. 
Citation: Farooq U, Malviya R, Sharma PK (2015) Design and Development of Multi Particulate System for Targeted Drug Delivery Using Natural Polymer. Pharm Anal Acta 6: 366. doi:10.4172/21532435.1000366

Page 6 of 8

\begin{tabular}{|c|c|c|c|c|c|c|}
\hline Formulation & Bulk density (gm/ml) & Tapped density (gm/ml) & Hausner's ratio & Carr's index (\%) & Angle of repose (o) & Particle size $(\mu \mathrm{m})$ \\
\hline $\mathrm{F} 1$ & $0.91 \pm 0.00$ & $1.01 \pm 0.05$ & $1.11 \pm 0.05$ & $9.59 \pm 4.23$ & $16.06 \pm 1.03$ & $316.00 \pm 43.42$ \\
\hline $\mathrm{F} 2$ & $0.91 \pm 0.04$ & $1.05 \pm 0.06$ & $1.44 \pm 0.43$ & $13.54 \pm 4.39$ & $16.14 \pm 3.07$ & $273.00 \pm 26.33$ \\
\hline F3 & $0.87 \pm 0.02$ & $1.02 \pm 0.01$ & $1.18 \pm 0.03$ & $15.47 \pm 2.13$ & $13.79 \pm 3.26$ & $331.20 \pm 36.08$ \\
\hline $\mathrm{F} 4$ & $0.90 \pm 0.03$ & $0.98 \pm 0.01$ & $1.10 \pm 0.04$ & $8.61 \pm 3.33$ & $14.33 \pm 2.20$ & $275.12 \pm 28.05$ \\
\hline F5 & $1.01 \pm 0.07$ & $1.20 \pm 0.09$ & $1.35 \pm 0.08$ & $15.65 \pm 5.53$ & $16.79 \pm 2.08$ & $240.72 \pm 22.51$ \\
\hline F6 & $1.06 \pm 0.09$ & $1.29 \pm 0.11$ & $1.22 \pm 0.11$ & $17.40 \pm 6.77$ & $12.92 \pm 0.73$ & $245.52 \pm 19.11$ \\
\hline $\mathrm{F} 7$ & $0.94 \pm 0.05$ & $1.06 \pm 0.03$ & $1.15 \pm 0.05$ & $13.14 \pm 4.17$ & $14.42 \pm 1.50$ & $283.44 \pm 31.70$ \\
\hline F8 & $0.96 \pm 0.48$ & $1.11 \pm 0.01$ & $1.17 \pm 0.06$ & $14.15 \pm 4.31$ & $15.77 \pm 3.96$ & $304.24 \pm 31.81$ \\
\hline F9 & $0.97 \pm 0.01$ & $1.05 \pm 0.05$ & $1.11 \pm 0.01$ & $14.17 \pm 0.00$ & $13.74 \pm 1.71$ & $280.02 \pm 25.58$ \\
\hline
\end{tabular}

Table 5: Micromeritic study data of microspheres.

\begin{tabular}{|l|l|l|l|l|l|l|l|l|}
\hline $\begin{array}{l}\text { Time } \\
(\mathbf{m i n})\end{array}$ & Formulations & F1 (\%) & F2 (\%) & F3 (\%) & F4 (\%) & F5 (\%) & F6 (\%) & F7 (\%) \\
\hline 0 & 0 & 0 & 0 & 0 & 0 & 0 & 0 \\
\hline 60 & 99 & 90 & 71 & 63 & 75 & 44 & 0 \\
\hline 120 & 74 & 85 & 69 & 60 & 70 & 38 & 55 \\
\hline 180 & 103 & 177 & 109 & 109 & 101 & 80 & 49 \\
\hline 240 & 89 & 89 & 54 & 49 & 64 & 25 & 70 \\
\hline 360 & Eroded & 8 & Eroded & Eroded & Eroded & Eroded & Eroded \\
\hline 720 & Eroded & Eroded & Eroded & Eroded & Eroded & Eroded & Eroded \\
\hline
\end{tabular}

Table 6: Comparative study of swelling index data in different formulation.

\begin{tabular}{|c|c|c|c|}
\hline Formulation & Days & Drug content (\%) & $\%$ Drug release (After $6 \mathrm{hrs}$ ) \\
\hline \multirow{4}{*}{ F1 } & 0 & 95.8 & 82.1 \\
\hline & 15 & 96.0 & 82.0 \\
\hline & 30 & 95.9 & 81.8 \\
\hline & 45 & 94.5 & 81.5 \\
\hline \multirow{4}{*}{ F3 } & 0 & 95.4 & 93.2 \\
\hline & 15 & 95.8 & 93.1 \\
\hline & 30 & 95.6 & 92.8 \\
\hline & 45 & 94.4 & 92.9 \\
\hline \multirow{4}{*}{ F5 } & 0 & 97.2 & 96.3 \\
\hline & 15 & 96.9 & 96.1 \\
\hline & 30 & 95.1 & 95.8 \\
\hline & 45 & 93.9 & 95.5 \\
\hline \multirow{4}{*}{ F7 } & 0 & 97.5 & 96.8 \\
\hline & 15 & 96.4 & 96.5 \\
\hline & 30 & 96.3 & 95.7 \\
\hline & 45 & 95.9 & 95.5 \\
\hline \multirow[t]{4}{*}{ F9 } & 0 & 98.4 & 99.2 \\
\hline & 15 & 98.3 & 98.8 \\
\hline & 30 & 97.8 & 98.5 \\
\hline & 45 & 97.7 & 98.2 \\
\hline
\end{tabular}

Table 7: Stability studies data of different formulations.

The slower in the release rate can be explained by the increase in the extent for swelling and the gel layer thickness that acted as a barrier for the penetration medium thereby retarding the diffusion of drug from the swollen microspheres. The first phase of drug loading might be negligible dissociation of microspheres in phosphate buffer mainly based on drug diffusion through the small pores and cracks.

The second phase exhibited a burst-like release pattern, which was accompanied by alginate and okra polymer disintegration. The results indicate that rate and extent of drug release decreased significantly with increase of concentration of calcium chloride and polymer, release data shows the following in increasing order F1< $\mathrm{F} 7<\mathrm{F} 3<\mathrm{F} 9<\mathrm{F} 4<\mathrm{F} 8<\mathrm{F} 5<\mathrm{F} 2<\mathrm{F} 6$. F6 formulation has given the best result of drug release as compare to other formulations (Figures 4 and 5).

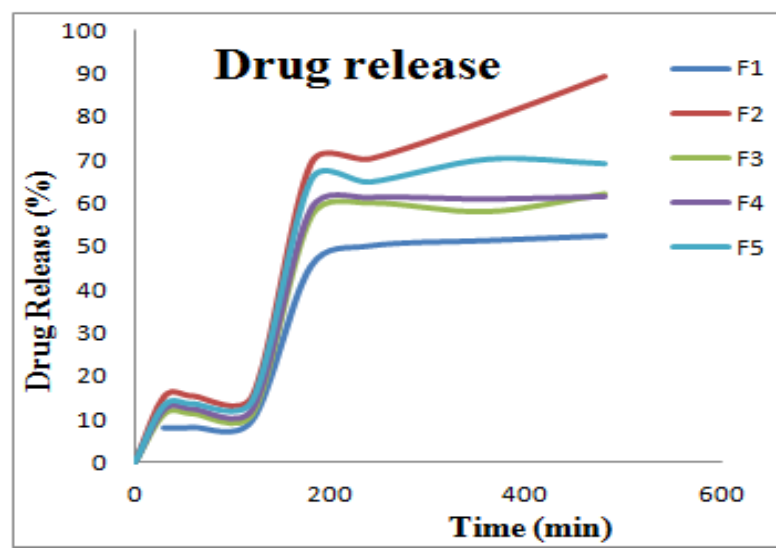

Figure 4: Comparative studies data of drug release of formulations (F1-F5).

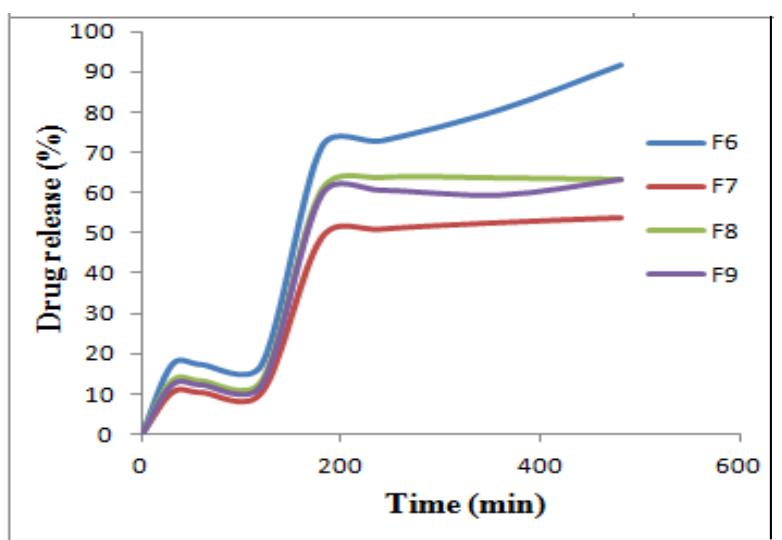

Figure 5: Comparative studies data of drug release of formulations (F6-F9). 


\begin{tabular}{|c|c|c|c|c|c|c|c|c|c|}
\hline \multirow{2}{*}{$\begin{array}{l}\text { Time } \\
(\min )\end{array}$} & \multicolumn{9}{|c|}{ Formulations } \\
\hline & F1 (\%) & F2 (\%) & F3(\%) & F4 (\%) & F5 (\%) & F6 (\%) & F7 (\%) & F8 (\%) & F9(\%) \\
\hline 0 & 0 & 0 & 0 & 0 & 0 & 0 & 0 & 0 & 0 \\
\hline 30 & 8.21 & 15.28 & 11.25 & 12.85 & 13.29 & 17.24 & 10.33 & 13.28 & 12.28 \\
\hline 60 & 8.30 & 15.29 & 11.27 & 12.90 & 13.54 & 17.25 & 10.33 & 13.28 & 12.29 \\
\hline 120 & 9.89 & 15.29 & 11.28 & 13.00 & 14.29 & 17.26 & 10.35 & 13.31 & 12.30 \\
\hline 180 & 45.61 & 69.33 & 57.12 & 59.62 & 65.60 & 71.17 & 48.69 & 60.80 & 59.60 \\
\hline 240 & 50.31 & 70.32 & 60.24 & 61.20 & 65.01 & 72.71 & 50.79 & 63.93 & 60.68 \\
\hline 360 & 51.54 & 79.25 & 58.20 & 60.84 & 70.31 & 80.52 & 52.45 & 63.82 & 59.50 \\
\hline 480 & 52.63 & 89.43 & 62.30 & 63.41 & 69.30 & 91.50 & 53.61 & 63.45 & 63.36 \\
\hline
\end{tabular}

Table 8: Comparative study drug release on the basis of release data of different formulations.

\section{Conclusion}

Natural polymers i.e. sodium alginate and extracted okra mucilage can be successfully used for preparation of losartan potassium microspheres as multi-particulate drug release modifiers. Various formulation variables such as okra mucilage concentration, calcium chloride concentration were used, which are influenced to the size distribution, mean particle size, surface morphology, swelling behaviour and in-vitro drug release. Multi-particulate formulations are brownish colour, spherical in shape, which has rough surface. All the formulations has different size due to the variability of okra polymer and calcium chloride in the formulations, F5 formulation has shown the minimum particle size i.e. $240.72 \mu \mathrm{m}$. The drug release from the microspheres was affected by the $\mathrm{pH}$ of the dissolution medium results more sustained effect in alkaline medium. Natural polymers were significantly affects mechanical properties, decreases porosity, controlled drug release due to increases swelling properties in higher $\mathrm{pH}$ of drug loaded microspheres. Therefore, one can assume that okra mucilage and sodium alginate are natural biopolymers used in pharmaceutical dosage forms by providing sustained release drug delivery systems and avoiding the dose related side effects in the entire physiological region. The entire process is feasible in an industrial scale and demands pilot study. Stability studies revealed that F1, F3, F5, F7 and F9 formulations showed slight decrease in drug content as well as \% drug release after at $0,13,30,45^{\text {th }}$ day. The results of drug release indicate that rate and extent of drug release decreased significantly with increase of concentration of calcium chloride and polymer, release data shows the following in increasing order $\mathrm{F} 1<\mathrm{F} 7<\mathrm{F} 3<\mathrm{F} 9<\mathrm{F} 4<\mathrm{F} 8<\mathrm{F} 5<\mathrm{F} 2<\mathrm{F} 6$. Since F6 formulation has given the best result of drug release due to lowest concentration of okra mucilage and calcium chloride.

\section{Acknowledgement}

Authors wish to thanks the IIT New Delhi to carry out SEM study

\section{References}

1. Farooq U, Malviya R, Sharma PK (2014) Advancement in microsphere preparation using natural polymers and recent patents. Recent Pat Drug Deliv Formul 8: 111-125.

2. Farooq U, Malviya R, Sharma PK (2014) Extraction and characterization of artocarpus integer gum as pharmaceutical excipient. Polim Med 44: 69-74.

3. Krishna LNV, Kulkarni PK, Dixit M, Lavanya D, Ravi PK (2011) Brief introduction of natural gums, mucilages and their application in novel drug delivery systems. International Journal of Drug Formulation and Research 2: 52-63.

4. Pawan P, Mayur P, Ashwin S (2001) Role of natural polymer in sustained release drug delivery system. International Research Journal of Pharmacy 2: 6-11.

5. Malviya R, Srivastava P, Kulkarni GT (2011) Application of mucilage in drug delivery. Advances in Biological Research 5: 1-7.

6. Sujitha B, Krishnamoorthy B, Muthukumaran M (2012) A role of natural polymers used in formulation of pharmaceutical dosage form. International Journal of Pharmacy and Technology 4: 2347-2362.
7. Dharmendra S, Surendra JK, Sujata M, Shweta S (2012) Natural excipients International Journal of Pharmaceutical and Biological Archives 3: 1029.

8. Girish KJ, Dhiren PS, Prajapatia DV, Jainb VC (2009) Gums and mucilages: versatile excipients for pharmaceutical formulations Gums and mucilages. Asian Journal of Pharmaceutical Sciences 4: 308-309.

9. Ogaji IJ, Nep El, Audu-Peter JD (2011) Advances in natural polymers as pharmaceutical excipients. Pharmaceutica Analytica Acta 3: 1-16.

10. Ahad HA, Sreenivasulu R, Rani EM, Reddy VB (2011) Preparation and evaluation of famotidine high density gastro retentive microspheres with synthetic and natural polymers. J Pharm Educ Res 2: 110-118.

11. Morkhade DM, Fulzele SV, Satturwar PM, Joshi SB (2006) Novel matrix forming materials for sustained drug delivery. Indian J Pharm Sci 68: 53-58.

12. Bhardwaj V, Kumar S (2012) Design and characterization of novel interpenetrating polymer network mucoadhesive microspheres of locust bean gum and PVA for controlled release of metformin HCl. Int Pharm Sci 2: 115-121.

13. Devrim B, Canefe K (2006) Preparation and evaluation of modified re- lease ibuprofen microspheres with acrylic polymers (eudragit) by quasi- emulsion solvent diffusion method: Effect of variables. Acta Poloniae Pharm Drug Res 63: $522-523$

14. Tavakoli N, Ghasemi N, Taimouri R, Hamishehkar H (2004) Evaluation of okra gum as a binder in tablet dosage forms. Iranian Journal of Pharmaceutical Research Res 2: 47.

15. Momoh MA, Akikwu MU, Ogbona JI, Nwachi UE (2009) In Vitro Study of Release of Metronidazole Tablets Prepared from Okra Gum, Gelatin Gum and their Admixture. Bio-Research 6: 339-342.

16. Kalu VD, Odeniyi MA, Jaiyeoba KT (2007) Matrix properties of a new plant gum in controlled drug delivery. Arch Pharm Res 30: 884-889.

17. Ogaji I, Noli O (2010) Film coating potential of okra gum using paracetamo tablets as a model drug. Asian Journal of Pharmaceutics 4: 130-134.

18. Attama AA, Adikwu MU, Amorha CJ (2003) Release of indomethacin from bioadhesive tablets containing carbopol 941 modified with Abelmuschus esculentus (okra) gum. Boll Chim Farm 142: 298-302.

19. Amin IM (2011) Nutritional Properties of Abelmoschus Esculentus as Remedy to Manage Diabetes Mellitus: A Literature Review. International Conference on Biomedical Engineering and Technology 11: 1-5

20. Nasipuri RN, Igwilo Cl, Brown SA, Kunle OO (1996) Mucilage from Abelmuschus esculentus (okra) fruits- a potential pharmaceutical raw material; part1; physicochemical properties. Journal of Pharmaceutical Research and Development 1: 22-28

21. Patel J, Bharadia P, Amin A, Patel M (2004) Formulation optimisation and evaluation of con- trolled release mucoadhesive microspheres of glipizide for oral delivery using factorial design. Drug Deliv 4: 48-53.

22. Farooq U, Sharma PK, Malviya R (2014) Extraction and Evaluation of Okra Mucilage as Pharmaceutical Excipient. Academic Journal of Plant Sciences 6: 168-172.

23. Ravi Kumar MN (2000) Nano and microparticles as controlled drug delivery devices. J Pharm Pharm Sci 3: 234-258.

24. Delie F, Blanco-Príeto MJ (2005) Polymeric particulates to improve ora bioavailability of peptide drugs. Molecules 10: 65-80.

25. Pamujula S, Graves RA, Kishore V, Mandal TK (2004) Preparation and in 
Citation: Farooq U, Malviya R, Sharma PK (2015) Design and Development of Multi Particulate System for Targeted Drug Delivery Using Natural Polymer. Pharm Anal Acta 6: 366. doi:10.4172/21532435.1000366

Page 8 of 8

vitro characterization of amifostine biodegradable microcapsules. Eur J Pharm Biopharm 57: 213-218

26. Lagarce F, Renaud P, Faisant N, Nicolas G, Cailleux A, et al. (2005) Baclofenloaded microspheres: preparation and efficacy testing in a new rabbit model. Eur J Pharm Biopharm 59: 449-459.

27. Bernkop-Schnürch A, Hornof M, Guggi D (2004) Thiolated chitosans. Eur J Pharm Biopharm 57: 9-17.

28. Ramesh SK, Mohan S, Dinesh M (2013) Pharmaceutical Excipient Development from Natural Source. Asian Journal of Pharmaceutical and Health Sciences 3 : 620-626

29. Farooq U, Sharma PK, Malviya R (2014) Extraction and Characterization of Almond (Prunus dulcis) Gum as Pharmaceutical Excipient. American-Eurasian J Agric \& Environ Sci 14: 269-274

30. Reddy MR, Manjunath K (2013) Pharmaceutical applications of natural gums, mucilages and pectins. International Journal of Pharmaceutical and Chemical Sciences 2: 1233-1239

31. Malviya R, Srivastava P, Bansal M, Sharma PK (2010) Okra Gum as Superdisintegrating Agents. Journal of Scientific and Industrial Research 69: 688-690.

32. Malviya R1 (2011) Extraction characterization and evaluation of selected mucilage as pharmaceutical excipient. See comment in PubMed Commons below Polim Med 41: 39-44.

33. FDA (2014) Indian Pharmacopoeia Version 1. Maharashtra, Mumbai.
34. Obodozie OO1, Ameh SJ, Afolabi EK, Oyedele EO, Ache TA, et al. (2010) A normative study of the components of niprisan--an herbal medicine for sickle cell anemia. See comment in PubMed Commons below J Diet Suppl 7: 21-30.

35. Farooq U, Malviya R, Bansal V, Sharma PK (2014) Characterization of Some Polymers as Pharmaceutical Excipient. Advances in Biological Research 8: 123-126.

36. Kulkarni GT, Gowthamarajan K, Rao B, Suresh B (2002) Evaluation of binding properties of selected natural gums. Journal of Scientific and Industrial Research 61: 529-532.

37. Malviya R, Srivastava P, Bansal M, Sharma PK (2010) Preparation and Evaluation of Disintegrating Properties of Cucurbita maxima Pulp Powder. International Journal of Pharmaceutical Sciences 2: 395-399.

38. Malviya R, Shukla P, Srivastava P (2009) Preparation, Characterization and Evaluation of Chitosan-Gum Arabic Coacervates as Excipient in Fast Disintegrating/ Dissolving Drug Delivery system. FABAD Journal of Pharmaceutical Sciences 34: 213-223.

39. Rahman Z1, Kohli K, Khar RK, Ali M, Charoo NA, et al. (2006) Characterization of 5-fluorouracil microspheres for colonic delivery. AAPS PharmSciTech 7: E47.

40. Soppimath KS, Aminbhavi TM (2002) Water transport and drug release study from cross-linked polyacrylamide grafted guar gum hydrogel microspheres for controlled release application. Eur J Pharm Biopharm 53: 87-89.

41. Gaba P, Singh S, Gaba S, Gupta GD (2011) Galactomannan gum coated mucoadhesive microspheres of glipizide for treatment of type 2 diabetes mellitus: In vitro and in vivo evaluation. Saudi Pharmaceutical Journal 19: 143-152. 